\title{
Child abuse: Legal aspects in Mexico
}

\section{Arturo Loredo-Abdalá, ${ }^{*}$ Roberto Ruiz Arciniega² and María Teresa Arias-González ${ }^{1}$}

${ }^{1}$ Coordination of Advanced Studies on Child Maltreatment-Prevention; '2Subdirectorate of Legal Affairs, Secretaría de Salud, Instituto Nacional de Pediatría. Mexico City, Mexico

\begin{abstract}
In Mexico, the complexity of the comprehensive care of a girl, boy or adolescent who is the victim of any form of child abuse requires the necessary legal knowledge for comprehensive management. Physicians probably lack sufficient knowledge of the laws to understand and correctly address the legal aspects immersed in the comprehensive care of this population group. Considering that child abuse has been characterized as a world-wide medical-social-legal problem, it is necessary to know the essential legal mechanisms to protect minors who are victims of it and understand the legal status of their families and of the probable aggressor. The purpose of this article is to present the existing legal framework in Mexico and the actions of world organizations in this area. It is necessary for the Political Constitution of the United Mexican States to be the basis on which legal behaviors related to child abuse, crime investigation and administration of justice are founded, as well as for international agreements on the subject, which have been signed by the government of Mexico, to be adhered to.
\end{abstract}

KEY WORDS: Child abuse. Legislation and jurisprudence. International legal framework. Mexico.

\section{Maltrato infantil: aspectos jurídicos en México}

\section{Resumen}

En México, la complejidad de la atención integral de una niña, niño o adolescente víctima de cualquier modalidad de maltrato infantil requiere el conocimiento jurídico indispensable para su manejo integral. Los médicos probablemente no tienen un conocimiento suficiente de las leyes para entender y atender correctamente los aspectos legales involucrados en la atención integral a este grupo de la población. Considerando que el maltrato infantil ha sido catalogado como un problema médico-social-legal de alcance mundial, se hace necesario el conocimiento de los mecanismos jurídicos indispensables para proteger a los menores que son víctimas y entender la condición legal de su familia y del probable agresor. El objetivo de este artículo es presentar el marco jurídico existente en México y las acciones en este rubro de las organizaciones mundiales. Se precisa que la Constitución Política de los Estados Unidos Mexicanos sea la base en la que se fundamenten las conductas legales vinculadas con el maltrato infantil, la investigación de delitos y la administración de justicia, así como los convenios internacionales sobre el tema, los cuales han sido suscritos por el gobierno de México.

PALABRAS CLAVE: Maltrato infantil. Legislación y jurisprudencia. Marco jurídico internacional. México. 


\section{Introduction}

In the field of Mexican pediatric medicine there are specific medical problems that demand that the doctor includes adequate knowledge of legal aspects in his/her academic training. Among them, euthanasia, organ transplantation, abortion, palliative care and non-accidental injuries to boys, girls and adolescents (BGA) stand out. ${ }^{1-4}$

Intentionally provoked violence against BGA has been known as Kempe syndrome, ${ }^{5}$ battered child syndrome $^{6}$ and currently it is recorded as child maltreatment (CM), according to the International Classification of Diseases. This entity is basically made up of four modalities: physical abuse, sexual abuse, emotional abuse and neglect. ${ }^{7}$

To establish the existence of this problem, several international and national definitions have been used. The World Health Organization (WHO) defines violence against children as follows: ${ }^{8}$

The intentional use of physical force or power, threatened or actual, against a child, by an individual or group, that either results in or has a high likelihood of resulting in actual or potential harm to the child's health, survival, development or dignity.

The Pan American Health Organization defines the problem in a similar form. ${ }^{9,10}$ In Mexico, the Official Mexican Standard NOM-046-SSA2-2005, on domestic and sexual violence and violence against women -Criteria for prevention, adheres to the definition proposed by WHO.11 At the National Institute of Pediatrics, a definition that covers almost all CM fundamental elements was created and has been used for two decades: ${ }^{12}$

Any intentional physical, sexual, psychological or negligent aggression or omission against a person under age, at any stage of life, that affects his/her biopsychosocial integrity, perpetrated regularly or occasionally, inside or outside his/ her domicile, by a person, institution or society based on their physical, intellectual or economic superiority.

This has enabled to better specify the clinical manifestations of the various modalities of the problem, facilitate the diagnosis of cases, their comprehensive care and short and medium-term patient surveillance.

Within the context of the comprehensive care of $\mathrm{CM}$ cases there is the legal aspect..$^{13}$ Clearly general practitioners, family doctors and pediatricians do not fully know the laws demanded by the comprehensive care of each case. This knowledge is basic, considering that CM has been cataloged as a medical-social-legal problem of global scope..$^{14,15}$
The purpose of this review is to point at the legal backgrounds of violence against BGA at global level and to specify the existing legal framework in Mexico in order for the health professional to recognize this legislation, which includes international agreements and regulations. ${ }^{12,13}$

\section{Brief historical review}

Since ancient times, Solon, one of the seven Greek wise men, already pointed out the need to protect children. Subsequently, Constantine "the Great" echoed of these claims and established the order to sanction with death, the father or older brother who killed or sold a child or sibling without a justification. . $^{16,17}$

By the end of the $19^{\text {th }}$ century, the English Society for the Prevention of Cruelty against Children was created. Over the years, several international institutions have appeared, whose purpose is to care for the rights and obligations towards BGA. In 1924, after World War I and during the Fifth Assembly of the League of Nations, the Geneva Declaration, also known as the International Save the Children Union Charter, was drafted. ${ }^{18}$

In 1948, the United Nations established the Universal Declaration of Human Rights; ${ }^{19} 11$ years later, in 1959, its General Assembly approved the Universal Declaration of the Rights of the Child. ${ }^{20}$ The intention is to provide the child with a happy childhood, with the enjoyment of rights and freedoms, urging society and the State to recognize them and exercise them through legal actions and definitions summarized in 10 statements (Table 1).

In 1979 (International Year of the Child), the preparations for the Convention on the Rights of the Child were initiated, which concluded on November 20, 1989. ${ }^{21}$ The fundamental characteristic of this document is its recognition and ratification by almost all countries of the world. The relevant points are:

1. Non-discrimination (article 2).

2. Best interests of the child (article 3).

3. The right to survival and development (article 6).

4. The views of the child (article 12).

Currently, in almost every country in the world it has been established that children must be protected under the motto "Best Interest of the Child". ${ }^{15}$

These considerations have a recent history and are the result of pressure from various civil societies, government institutions or individuals interested in the subject, which has allowed apparently "utopian" ideas, desires and considerations to become a reality. 
Table 1. Rights and freedoms of girls and boys $\mathbf{s}^{20}$

- The right to equality, without distinction on account of race, religion or national origin

- The right to special protection for the child's physical, mental, spiritual and social development

-The right to a name and a nationality

- The right to health, nutrition, housing and recreation

- The right to special education and care for the girl, boy or adolescent who is physically and mentally handicapped or socially disabled

- The right to understanding and love by parents and society

- The right to free education and recreational activities

- The right to be among the first to receive help, protection and relief in case of disaster

- The right to protection against neglect and exploitation at work

- The right to be brought up in a spirit of solidarity, understanding, friendship and justice among peoples

Instruments resulting from agreements or platforms of action and conferences held by the United Nations Organization or by the Organization of American States are located within the international legal framework. ${ }^{22-29}$

\section{Actions in Mexico}

Since the middle of the twentieth century, in Mexico there is a legal framework that encompasses all international and national regulations and treaties that take care of providing BGA with permanent protection of their rights. ${ }^{30}$

Mexico, as a member state of the United Nations and the Organization of American States, has adopted international legislative measures aimed at safeguarding children's rights, which enrich existing laws in Mexico. The Chamber of Senators of the Honorable Congress of the Union approved the adoption of these international agreements through an agreement published in the Official Journal of the Federation on July 31, 1990 and with a promulgation decree on January $25,1991 .{ }^{31}$

The Political Constitution of the Mexican United States is the country's Supreme Law to legally regulate this situation. This way, the Mexican government demands to recognize BGA as rights holders, in accordance with the principles of universality, interdependence, indivisibility and progressivity established in article 1 of the Constitution. ${ }^{32}$
Among these actions, the reform added to constitutional article 4 stands out, which textually establishes the parents' duty to preserve the right of minors to have their needs satisfied and to physical and mental health, empowering secondary laws to determine the required support for their protection by public institutions. ${ }^{32}$

In 2014, the General Statute of Girls, Boys and Adolescents Rights was issued in order to guarantee full exercise, respect, protection and promotion of the human rights of this age group, and for the creation, regulation and operation of the National System for BGA Rights Comprehensive Protection in order for the State to fulfill its responsibility. ${ }^{33}$

International treaties and the laws established in the Civil Code, Federal Code of Civil Procedures, Federal Criminal Code, and Criminal Procedures Code adhere to the above, thus constituting the basic legal framework that supports legal behaviors related to maltreatment of minors, crime investigation and administration of justice.

On the other hand, there are other laws, derived from those above-mentioned, which specify the protection of minors. ${ }^{34-40}$

\section{Requirements for health professionals: specific regulations}

In 2005, the Official Journal of the Federation published the modifications of the Official Mexican Standard NOM-190-SSA1-1999, on the provision of health services -Criteria for the medical care of domestic violence, which finally became NOM-046-SSA2-2005, on domestic and sexual violence and violence against women -Criteria for prevention and care. ${ }^{11}$

In 2013, the Official Journal of the Federation published the General Law of Victims, whose purpose is to guarantee the rights of victims and for them to have access to public goods and services, in an effective appropriation of their human rights, compelling all authorities of all three constitutional powers, as well as any public or private agency, body or institution that safeguards the protection of victims. All of this, as a response from the State to society in the face of violence and insecurity caused by an unacceptable violation of human rights.

In order for this objective to be achieved, the Executive Commission for the Attention of Victims is the newly-formed organization responsible for guaranteeing the representation and direct participation of victims and civil society organizations. ${ }^{41}$ 


\section{Considering child maltreatment as a medical-social-legal problem}

In daily practice, proper intervention of doctors, paramedical professionals and legal medicine specialists is required to comprehensively look after a case of CM. Therefore, it is essential to have a sound knowledge of the legal aspect of the issue in order to avoid obstacles in the legal handling of each patient. ${ }^{42}$

The legal actions, inherent in this problem are:

- Actions that are the responsibility of the medical and paramedical staff.

- Actions that depend on representatives of the law.

\section{Actions that are responsibility of the medical staff}

In this framework, the situations that prevent or hinder compliance with the corresponding report are considered:

a) The treating physician or first professional who has contact with the alleged victim usually lacks the necessary knowledge to establish the $\mathrm{CM}$ diagnosis and is therefore unaware that a complaint must be filed reporting the facts.

b) The doctor may suspect and even can establish the diagnosis of probable $\mathrm{CM}$, but he/she ignores know how to act in the legal sphere.

c) In some cases, the doctor is able to establish a diagnosis of probable $\mathrm{CM}$ and recognizes that he/she should resort to the corresponding legal authority; however, he/she does not because he/she assumes that it is a waste of time, because he/she doesn't want to leave his/her working center to attend the Public Prosecutor's office, or because his/her workload does not allow establishing the relationship with the professional of the legal area.

d) The doctor may assume that legal action does not meet his/her expectations. For example, when the authority has reinstated the minor to his/her family nucleus, where the aggressor is found, or because the minor has been channeled to a temporary shelter whose conditions, far from helping him/her, become an additional risk for the child. Frequently, both situations favor that the minor is victim of ill-treatment again.

e) With some frequency, the authority does not accept the suggestion of using the family or institutional network that has been specified by the treating group.

\section{Actions that are the responsibility of the legal area}

In this framework, the following situations can be considered:

a) Ignorance of the legal authority about the variety and clinical expression of $\mathrm{CM}$, as well as the social environment that revolves around this pathology.

b) In the absence of physical manifestations or poorly specific clinical evidence (touching, exploitation through prostitution, child pornography, disease caused by relatives, etc.), it is difficult for the corresponding authority to establish or sustain the diagnosis of this pathology; therefore, adequate protection required by the child is not granted.

c) In making a decision, the representative of the law may be influenced by prejudices that prevent an adequate assessment of the case

d) The individual responsible for the law does not accept the options of short-, medium- and longterm surveillance that the medical and paramedical group may propose.

e) No short and medium term mandatory patient surveillance is established; therefore, an evaluation and validation that the decision made has been the best option for the child and for his/her family cannot be carried out.

f) It is possible that the representative of the law lacks the training to apply the law to the benefit of the victims, their relatives and even the aggressor; frequently, he/she does not consider social, cultural, environmental or religious aspects or the possibility of a neuropsychiatric disease in some family member.

g) The representative of the law does not consider the child's opinion on how CM occurred, especially when the child is already old enough to express his/her opinion.

h) The representative of the law does not prevent patient further victimization by repeating interviews and medical examinations.

i) The representative of the law may ignore the action protocols issued by the Supreme Court of Justice or the Executive Commission for Attention to Victims of Crime, among others.

The care provided by a health professional to a BGA who is the victim of $\mathrm{CM}$ entails a legal responsibility that is indicated in articles 322 and 325 of the Criminal Code. ${ }^{43}$ 
It is necessary for the medical and paramedical personnel of our country to know the existence of specific articles regarding inadequate action or omission in the care that victims of any CM modality may receive, which indicate different fines, deprivation of personal liberty or professional license suspension. The latter will be definitive in case of reiteration, and the professional will be forced to repair the damage caused by his own acts and those of his/her auxiliaries, when they do not act in accordance with received instructions.

Articles 15, 202 and 301 of the Criminal Code for The Federal District (now Mexico City) are related to the practice of the profession. ${ }^{43}$

Currently, the Regulations of the General Statute of Health Regarding the Provision of Medical Care Services ${ }^{44}$ are the health set of rules that mandate health personnel to notify to the Public Prosecutor's Office or other relevant authorities (Federal or local Attorney General's Office and National System for the Comprehensive Development of the Family) any case of CM, as well as cases where medical services are required due to the existence of injuries or other signs that are presumably linked to the commission of illegal acts.

In the presence of family or sexual violence, notification is mandatory as indicated by NOM-046SSA2-2005, numeral 6.5, and should be presented before the Public Prosecutor's Office for "the effects of procurement of justice as appropriate" (numeral 5.10), using a form that can be found in that regulation. Each probable case should be notified to the Ministry of Health using the epidemiological surveillance form SUIVE-1-2000 for the corresponding epidemiological surveillance (numeral 5.11). ${ }^{11,45}$

In the face of this legal reality, health professionals (doctors and paramedics) are required to know and apply the corresponding laws in the care of a patient. Finally, in this article, the legal consequences when the health professional incurs the omission of complying with the law during the care of a $\mathrm{CM}$ victim are reiterated. These can be:

- Professional license revocation.

- The corresponding fine.

- Deprivation of personal liberty.

\section{Conclusions}

As a general principle of law, ignorance of the law does not exempt the responsibility of its compliance, as stated in article 6 of the Civil Code.
- When a minor presents with injuries, regardless of their origin, the doctor or the health professional should file a medical report with the relevant authority.

- The diagnosis of CM should be made in consensus by professionals who know the subject (pediatric or other specialty doctors, social worker, psychologist or psychiatrist, lawyer, mainly). At the National Institute of Pediatrics this action is performed at the Clinic for the Comprehensive Care of the Maltreated Child.

- When this possibility does not exist, the corresponding authority should request professional support from experts in the field.

- Health professionals, teachers or any family member who suspect CM but lack an institutional infrastructure, can file an anonymous complaint or a telephone, written or direct voluntary confession to the National System for the Comprehensive Development of the Family, where complaints are received 24 hours a day, including Saturdays, Sundays and holidays.

- In case of a CM diagnosis, the authority will specify the behavior to be followed with the child, the family and the aggressor.

\section{Referneces}

1. Aréchiga-Ornelas GE. Cuidados al final de la vida en la niñez. En: Herrera-Fragoso AA. Eutanasia: cuidados paliativos y atención al final de la vida. México: Editores de Textos Mexicanos; 2019.

2. Basilio-Olivares A, Díaz-De León-Ponce M, Cruz-Vega F. Posturas médicas frente al trauma. En: Díaz-De León-Ponce MA, Basilio-Olivares A, Cruz-Vega F, Briones-Garduño JC, editores. Trauma: un problema de salud en México. México: Academia Nacional de Medicina de México/ Intersistemas/Consejo Nacional de Ciencia y Tecnología; 2016.

3. Híjar-Medina MC. Los accidentes como problema de salud pública en México. Retos y oportunidades. México: Academia Nacional de Medicina de México/Intersistemas/Consejo Nacional de Ciencia y Tecnología; 2014

4. Larracilla-Alegre J. Investigación y ética en pediatría. Consideraciones generales. Cir Ciruj. 2003;71:404-408.

5. Caffey J. The parent-infant traumatic stress syndrome (Caffey-Kempe síndrome) (battered babe syndrome). Am J Roentgenol Radium Ther Nucl Med. 1972;114:218-229.

6. Kempe CH, Silverman FN, Steel BF, Droegemueller W, Silver HK. The battered child syndrome. JAMA. 1962:181:17-24

7. Organización Panamericana de la Salud. Clasificación estadística internacional de enfermedades y problemas relacionados con la salud. EE. UU.: OPS; 1995.

8. Fondo de las Naciones Unidas para la Infancia. Informe mundial sobre la violencia contra los niños y niñas. Ginebra: Fondo de las Naciones Unidas para la Infancia; 2006.

9. Organización Panamericana de la Salud. Informe mundial sobre la violencia y la salud. EE. UU: OPS, Oficina Regional para las Américas de la Organización Mundial de la Salud, 2003.

10. Organización Panamericana de la Salud. INSPIRE. Siete estrategias para poner fin a la violencia contra los niños y las niñas. EE. UU: OPS; 2017.

11. Norma Oficial Mexicana NOM-046-SSA2-2005. Violencia familiar, sexual y contra las mujeres. Criterios para la prevención y atención. México: Diario Oficial de la Federación; 2005.

12. Perea-Martínez A, Loredo-Abdalá A, Trejo-Hernández J, Báez-Medina V, Martín-Martín V, Monroy-Villafuerte A, et al. El maltrato al menor: propuesta de una definición integral. Bol Med Hosp Infant Mex. 2001;58:251-258.

13. Camarena Rivera ML. El marco jurídico de las niñas y los niños. Rev Iberia Cienc Soc Hum. 2016;5:93-134. 
14. McMenemy MC. WHO recognizes child abuse as a major problem. Lancet. 1999;353:1340.

15. Díaz HJ, Ayuga MD. Los derechos del niño. En: Maltrato infantil. Prevención, diagnóstico e intervención desde el ámbito sanitario. España: Dirección General de Prevención y Promoción de la Salud; 1995.

16. Petit E. Tratado elemental del derecho romano. Argentina: Araujo; 1940.

17. Loredo-Abdalá A. Generalidades del maltrato infantil. En: Loredo-Abdalá A Maltrato en niños y adolescentes. México: Editores de Textos Mexicanos: 2004.

18. Morier A. La Déclaration des droits de l'enfant. Revue Internationale de la Croix-Rouge. 1963;533:209-216.

19. Organización de las Naciones Unidas. Declaración universal de derechos humanos. Francia: ONU; 1948.

20. Organización de las Naciones Unidas. Declaración de los derechos de niño. ONU; 1959.

21. Organización Mundial de las Naciones Unidas. Convención sobre los derechos del niño. Ginebra: ONU; 1989.

22. Espinosa-De León VM. La protección a la niñez en México. Revisión histórica. Rev Mex Pediatr. 1972;41:565-577.

23. Comisión Interamericana de Derechos Humanos. Relatoría sobre los derechos de la niñez. EE. UU.: CIDH; 2006.

24. Fondo de las Naciones Unidas para la Infancia para América Latina y Caribe [sitio web. Niñas y niños con discapacidad. Panamá: Fondo de las Naciones Unidas para la Infancia para América Latina y Caribe.

25. Fondo de las Naciones Unidas para la Infancia para América Latina y Caribe. Convención de La Haya sobre la protección en menores y la cooperación en materia de adopción internacional. Países Bajos: OEA; 1986.

26. Organización de Estados Americanos. Convenio sobre los aspectos civiles de la sustracción internacional de menores. Países Bajos: OEA; 1980.

27. Organización de los Estados Americanos Convención interamericana sobre obligaciones alimentarias. Uruguay: OEA; 1989.

28. Organización de los Estados Americanos. Convención interamericana sobre restitución Internacional de menores. Uruguay: OEA; 1989.
29. Organización de las Naciones Unidas. Convención sobre el consentimiento para el matrimonio, la edad mínima para contraer matrimonio y el registro de matrimonios. EE. UU.: ONU;1983.

30. Secretaría de Gobernación [sitio web. Compilación de tratados internacionales. Menores de 18 años de edad; niños, niñas y adolescentes. México: Secretaría de Gobernación; 2017.

31. Decreto promulgatorio de la convención sobre los derechos de los niños. México: Diario Oficial de la Federación 1991 Ene 25.

32. Constitución política de los Estados Unidos Mexicanos. México: Diario Oficial de la Constitución; 1997.

33. Ley general de los derechos de niñas, niños y adolescentes. México: Diario Oficial de la Federación; 2018

34. Ley de asistencia y prevención de la violencia familiar. México: Diario Oficial de la Federación; 1996.

35. Ley general de educación. México: Diario Oficial de la Federación; 2018

36. Ley federal del trabajo. México: Diario Oficial de la Federación; 2018.

37. Ley general de salud. México: Diario Oficial de la Federación; 2018.

38. Ley de asistencia social. México: Diario Oficial de la Federación; 2018.

39. Sistema Nacional para el Desarrollo Integral de la Familia. Estatuto Orgánico del Sistema Nacional para el Desarrollo Integral de la Familia. México: Diario Oficial de la Federación; 2016.

40. Ley para el tratamiento de menores infractores, para el Distrito Federa en materia común y para toda la república en materia federal. México: Diario Oficial de la Federación; 1991.

41. Ley general de víctimas. México: Diario Oficial de la Federación; 2017.

42. Loredo-Abdalá A. Maltrato en el niño. México: McGraw-Hill Interamericana; 2001.

43. Código penal para el Distrito Federal. México: Gaceta Oficial del Distrito Federal; 2016

44. Reglamento de la ley general de salud en materia de prestación de servicios de atención médica. México: Diario Oficial de la Federación; 2016.

45. Contreras-López CF. Actualidades de la legislación mexicana sobre el uso de datos personales en la atención médica y la confidencialidad como derecho del médico. Gac Med Mex. 2018;154:693-697. 